\title{
Eugène Sue, Correspondance générale
}

\section{Lise Sabourin}

\section{(2) OpenEdition}

\section{Journals}

Édition électronique

URL : http://journals.openedition.org/studifrancesi/525

DOI : 10.4000/studifrancesi.525

ISSN : 2427-5856

\section{Éditeur}

Rosenberg \& Sellier

\section{Édition imprimée}

Date de publication : 1 avril 2015

Pagination : 170

ISSN : 0039-2944

\section{Référence électronique}

Lise Sabourin, «Eugène Sue, Correspondance générale », Studi Francesi [En ligne], 175 (LIX | I) | 2015 mis en ligne le 01 avril 2015, consulté le 18 septembre 2020. URL : http://journals.openedition.org/ studifrancesi/525 ; DOI : https://doi.org/10.4000/studifrancesi.525

\section{Ce document a été généré automatiquement le 18 septembre 2020}

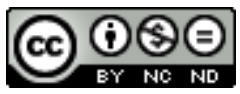

Studi Francesi è distribuita con Licenza Creative Commons Attribuzione - Non commerciale - Non opere derivate 4.0 Internazionale. 


\title{
Eugène Sue, Correspondance générale
}

\author{
Lise Sabourin
}

\section{RÉFÉRENCE}

EUGÈnE SUE, Correspondance générale, t. II, éditée par Jean-Pierre GALVAN, Paris, Honoré Champion, 2013, pp. 953.

1 Jean-Pierre Galvan délivre le deuxième tome de la Correspondance générale d'Eugène Sue, couvrant la période 1841 à 1845 qui correspond à l'accès à la célébrité du romancier de Mathilde, des Mystères de Paris et du Juif errant. Comme le précise son introduction (pp. 7-13), ces lettres permettent de rétablir quelques vérités sur les conditions d'écriture et de publication de ces œuvres majeures: ce n'est pas seulement le mode de parution en feuilleton, mais aussi son évolution personnelle qui font du romancier maritime des débuts l'auteur à succès populaire que devient Sue.

2 La prépublication en périodique a certes convaincu son éditeur Gosselin de passer pour ces romans de deux volumes à quatre, et même à six et huit, mais peu à peu la méfiance s'installe: le tiers d'inédit entre journal et livre exigé par l'éditeur mécontente les abonnés de «La Presse» qui voient remplacer la fin de Mathilde par des résumés dus à Gautier. De ce fait, Les Mystères de Paris sont publiés aux «Débats», Bertin obtenant l'intégralité du roman en feuilleton. Quant au Juif errant, il suscite un procès entre «Le Constitutionnel» et «La Presse», tandis que Sue se voit contester par Gosselin de le publier chez Paulin. Le caractère conciliant du romancier n'empêche pas non plus la collaboration avec Goubaux pour adapter au théâtre Les Mystères de Paris de tourner au cauchemar.

Parallèlement son écriture évolue, tournant au work in progress par l'influence des réactions du public qui pousse Sue à infléchir son projet. Ainsi le délai entre écriture et publication se réduit-il dangereusement, même si le romancier s'impose parfois des interruptions de parution pour mieux maîtriser et réviser son texte. Ainsi également l'identification que font les lecteurs entre son héros Rodolphe et l'auteur en redresseur de torts philanthrope l'incite-t-elle à accentuer l'éclosion de ses préoccupations 
sociales, morales et politiques. Sa fréquentation des intellectuels engagés, ses rencontres avec le milieu saint-simonien préparent la carrière politique de ce romancier désormais très sollicité.

4 Selon les principes de la collection, cette édition scientifique rigoureuse est collationnée sur autographes ou première parution, annotée et munie d'un dictionnaire des correspondants, outre l'index des noms cités. 